\title{
The Effect of Z-Libraries (Enhanced Libraries) on the Reading Level and Creative Reading of the Students at High Schools: Çankaya Sample
}

\section{Nurhan Girgeç, Melike Cerit}

The aim of this study is to identify the significant increase in the reading level of the students at high schools after the establishment of the Z-Libraries and to show whether creative reading is carried out more consciously at high schools that have Z-libraries.

For this purpose, a questionnaire was applied to 400 students in 4 different types of high schools with a similar score range in Çankaya, the district of Ankara. The fact that there is Z-library in the researcher's institution, and the researcher's review of records of the books borrowed before the Z-library was established, and the records of the books borrowed after the Z-library was established, have given the researcher the opportunity to make more effective observations. Data analysis was carried out with the SPSS program.

The questionnaires applied, the research conducted and the results of the participated observation can be interpreted in this way: Students at the high schools that have Z-library read more and fulfil creative reading more consciously. At the same time, they are aware of the benefits and environment provided by Z-library, and they use the library more effectively than the students who use the library at other high schools that have an ordinary library.

As a result, with its wide-range of access to knowledge, with its ergonomic design and the diversity of collections and its systematic functioning, Z-Libraries not only provide students with a good reading habit, but also enable them creative reading awareness. It is no doubt the library type that serves the needs of the 21st century should be the Z-Libraries based on technology.

Keywords: Reading, Reading Culture, Library, Z-library, Reading Skills

\section{Introduction}

eading is the most effective factor for an individual to shape one's personality, to gain a
genuine point of view that will increase the reading habit, and to get a creative disposition which will work towards a solution in the face of problems. There is no doubt that the 
way for a nation to acquire contemporary civilization level is to have a rooted and progressive reading culture. Underestimation of reading in Turkey reveals many problems and causes to fall behind in our country's socio-economic, cultural, educational areas.

According to PISA, the fact that Turkey's reading skills falls behind several countries indicates that we have not reached the adequate level in this area. Therefore, the Ministry of National Education (MoNE) has initiated the work on improvement of school libraries as it is believed that the improvement of reading skills will bring along solutions to many problems. The Z-libraries started to be installed in schools are the biggest steps taken in this direction. A school with a functional library is the place where reading cultures is most effective and constantly developing. At the same time, with this project, it is aimed to increase creative reading and convey reading skills to equipped individuals throughout the country

Establishment of a Z-library where the researchers work and are schooled and personally ascertain the change in book borrowing by examining book borrowing records before and after the establishment of the Z-library, is the starting point of the project.

It was thought to constitute a model for other schools with this study, by examining the impact of Z-libraries on reading level and skills via Çankaya sample.

\section{Research Method}

A questionnaire was applied to the students of 400 secondary education institutions in four different schools in Çankaya district of Ankara, which received students at a base point level close to each other. Two of these schools have normal libraries while the other two have Z-libraries. The Z-libraries in these schools were opened at the beginning of 2015-2016 academic year. While the questionnaire consisted of 30 questions, six additional questions were asked to the students in the schools which had a Z-library. The questionnaire was prepared to be filled in five to six minutes. Surveys were conducted at randomly selected 9th, 10th and 11th grades. Data analysis was carried out with the SPSS program.

In addition, studies about the Z-library project by the MoNE and the periodicals prepared in this subject have been examined. 


\section{Findings}

\subsection{Reading Level of Secondary School Students in Turkey according to PISA Results}

The PISA (Programme for International Student Assessment) measures reading skills in the context of using knowledge in everyday life, making logical conclusions, interpreting and solving problems related to various situations. The results of the PISA 2009, 2012 and 2015 published by the MoNE were examined and reached the results in the table below. (Access: April 19, 2015) Accordingly, reading level of secondary education students in Turkey is below OECD average. The ranking among the participating countries is also quite low.

\begin{tabular}{|c|c|c|c|}
\hline & PISA 2015 & PISA 2012 & PISA 2009 \\
\hline OECD Average & 493 & 496 & 493 \\
\hline $\begin{array}{c}\text { All Countries } \\
\text { Average }\end{array}$ & 460 & 471 & 464 \\
\hline Turkey Average & 428 & 475 & 464 \\
\hline Ranking & 50 & 42 & 39 \\
\hline $\begin{array}{c}\text { Number of } \\
\text { Participating } \\
\text { Countries }\end{array}$ & 72 & 65 & 65 \\
\hline
\end{tabular}

\subsection{Library and Librarianship}

The term "bibliothek" which is commonly used in the western world means "library" and it is originally ancient Greek, and "biblion" means where books are stored. The Turkic library word (kütüphane) is derived from Persian and Arabic words books (kütüb) and Persian household (hane) and means the house of books. In both languages, the library term is used to mean the place where books are stored. Libraries are service businesses which function in the collection, storage and distribution of obtained information. 
The libraries, which have an important place in the Turkish cultural life and supposed to bear important responsibilities of the nations in the field of education, culture and science, have been functioning since the Ottoman era, but have begun to be considered in the first years of the Republic in contemporary sense. Upon Atatürk's instructions in 1934, the Compilation Act incorporating the concepts of Turkey Bibliography and National Library, which closely concerned Turkey's librarianship, came into force and the National Library was established in 1948. These developments show that the understanding of librarianship should be at the forefront of a country's path to modernization. (At1lgan, 1995)

\subsection{School Libraries in Turkey}

Turkey paid close attention to librarianship which gained a special importance at the beginning of the $20^{\text {th }}$ century and closely followed up the operation of school libraries which were shown as good examples. However, it fell behind with respect to school librarianship in the country. (All articles together: pg. 17-26) The results of the lack of infrastructure gradually alienated the Turkish society from reading culture. School librarians took a major step, especially in the 1960s, by using information technologies to provide more active services. (Çetintaş, 2015) However, there are still serious problems at school libraries in Turkey. The regulations which should be enforced in the libraries of secondary education institutions are not being applied in many schools. For instance, the internet connection was interrupted in two high schools because of the other requirements of these schools in Buca district of İzmir. Or the fact that some schools have not yet had an internet connection is the subject matter of a separate discussion. In some schools it is seen that school libraries are transformed into classrooms due to physical insufficiencies. In addition, many school libraries are not being updated. (Akkaya, 2015)

The decrease in reading rate caused by some disruptions such as these and the PISA results have made MoNE act in order to improve school libraries. The Z-libraries started to be brought into effect as of 2012 and were established in 327 schools in 2013-2014. In addition, there is a $7.2 \%$ decrease in the number of students who never go to libraries after Z-libraries. (Taştan, 2015) Considering their opportunities and benefits, it can be said that the opening of Z-libraries is the greatest step on this path while the demands of the global society and information age aim to blend librarianship and to reform them in accordance with changing world standards. As access to 
information is easy in this era, it enabled students who spend most of their time and library at schools to embrace reading culture and libraries and influenced many students in a positive way. The detection of these findings and the observation of the increase call attention to the fact that this project should be given weight to.

At the IFLA (International Federation of Library Associations and Institutions) / UNESCO School Library Declaration, it is stated that "The school library encompasses the knowledge and ideas that are essential for providing successful services in today's knowledgebased society. The school library equips students with life-long learning skills and improves their imagination while ensuring that students live as responsible citizens." (Erişim: January 2016)

\subsection{Questionnaire Analysis:}

\section{Table 1: Do you have a reading habit?}

\begin{tabular}{|c|c|c|c|c|c|c|c|}
\hline \multirow{2}{*}{$\begin{array}{c}\text { Library } \\
\begin{array}{c}\text { Status at } \\
\text { Schools }\end{array}\end{array}$} & \multicolumn{2}{|c|}{ Yes } & \multicolumn{2}{c|}{ Partially } & \multicolumn{2}{c|}{ No } & \multirow{2}{*}{ Total } \\
\cline { 2 - 7 } & Frequency (f) & Percentage (\%) & Frequency (f) & Percentage (\%) & Frequency (f) & Percentage (\%) \\
\hline Z-library & 127 & 31,5 & 57 & 14,3 & 16 & 4 & 200 \\
\hline $\begin{array}{c}\text { Normal } \\
\text { Library }\end{array}$ & 72 & 18 & 74 & 18,5 & 54 & 13,5 & 200 \\
\hline TOTAL & 198 & 49,5 & 131 & 32,8 & 70 & 17,5 & 400 \\
\hline
\end{tabular}

The interpretation of the first question in the questionnaire survey aims to determine secondary school students' habit of reading the books taking into account the library status in the schools; based on the obtained percentages to reach the conclusion that students' habit of reading books is higher in Z-library schools than the students with a regular library in their schools. In Table 1, it is seen that $31.5 \%$ of the students answered "Yes" to the question "Do you have a reading habit?" and this ratio is $18 \%$ in the regular library group. In addition, the percentage of students who opt for the "Partially" option is $14.3 \%$ in the Z-library group and $18.5 \%$ in the normal library group. Finally, in the Z-library group, students who do not have a reading habit cover a rate of $4 \%$, while 
the normal library group covers a rate of $13.5 \%$.

Table 2: How many books do you read on average per month?

\begin{tabular}{|c|c|c|c|c|c|c|c|c|c|}
\hline \multirow{2}{*}{$\begin{array}{l}\text { Library } \\
\text { Status at } \\
\text { Schools }\end{array}$} & \multicolumn{2}{|c|}{$1-2$} & \multicolumn{2}{|c|}{$3-4$} & \multicolumn{2}{|c|}{5} & \multicolumn{2}{|c|}{ None } & \multirow{2}{*}{ Total } \\
\hline & $\begin{array}{l}\text { Frequency } \\
\text { (f) }\end{array}$ & $\begin{array}{c}\text { Percentage } \\
(\%)\end{array}$ & $\begin{array}{l}\text { Frequency } \\
\text { (f) }\end{array}$ & $\begin{array}{c}\text { Percentage } \\
(\%)\end{array}$ & $\begin{array}{l}\text { Frequency } \\
\text { (f) }\end{array}$ & $\begin{array}{c}\text { Percentage } \\
(\%)\end{array}$ & $\begin{array}{l}\text { Frequency } \\
\text { (f) }\end{array}$ & $\begin{array}{c}\text { Percentage } \\
(\%)\end{array}$ & \\
\hline Z-library & 97 & 24,3 & 57 & 14,3 & 28 & 7,0 & 18 & 4,5 & 200 \\
\hline $\begin{array}{l}\text { Normal } \\
\text { Library }\end{array}$ & 112 & 28,0 & 23 & 5,8 & 10 & 2,5 & 55 & 13,8 & 200 \\
\hline TOTAL & 209 & 52,3 & 80 & 20,1 & 38 & 9,5 & 73 & 18,3 & 400 \\
\hline
\end{tabular}

In Table 2, the question "How many books do you read on average per month?" was directed to the students and it has been associated with the library status in the schools and it was concluded that more books are read in schools with Z-libraries. Those who read 1-2 books a month constitute a rate of $24.3 \%$ in the Z-library group and $28.0 \%$ in the normal library group. The percentage of students who read 3-4 books a month is $14.3 \%$ in the Z-library group and $5.8 \%$ in the normal library group. Students who read 5 books a month have $7.0 \%$ in the Z-library group and $2.5 \%$ in the normal library group. Unlike these, the students who prefer "None" make up a rate of $4.5 \%$ in the Z-library group and $13.8 \%$ in the normal library group. Based on these results, it was observed that the students in the Z-library group read 1-2 or 3-4 books predominantly in the month, but it is seen that in the normal library group, the rate of students who predominantly read 1-2 books a month and who read none are higher than the ones in the Z-library group.

Table 3: Is there a library at your school?

\begin{tabular}{|c|c|c|c|c|c|c|c|}
\hline \multirow{2}{*}{$\begin{array}{l}\text { Library } \\
\text { Status at } \\
\text { Schools }\end{array}$} & \multicolumn{2}{|c|}{ There is. } & \multicolumn{2}{|c|}{ There is not. } & \multicolumn{2}{|c|}{ There is a Z-library. } & \multirow{2}{*}{ Tota } \\
\hline & Frequency (f) & Percentage $(\%)$ & Frequency (f) & Percentage $(\%)$ & Frequency (f) & Percentage (\%) & \\
\hline Z-library & 15 & 3,8 & 1 & ,3 & 184 & 46,0 & 200 \\
\hline $\begin{array}{l}\text { Normal } \\
\text { Library }\end{array}$ & 193 & 48,3 & 3 & ,8 & 4 & 1,0 & 200 \\
\hline TOTAL & 208 & 52,1 & 4 & 1,1 & 188 & 47,0 & 400 \\
\hline
\end{tabular}


In Table 3, we can say that despite the existence of Z-library in their schools, $3.8 \%$ of the students are not aware of the Z-library yet. In addition to this, a rate of $0.3 \%$ that is 1 person thinks that there is no library in the school. Finally, $46 \%$ of the students reported that there were Z-libraries in their schools. In the normal library group, $48.3 \%$ of the students gave the answer "There is", while $0.8 \%$ think that there is no library in the school. Since they do not have information about the Z-library, $1.0 \%$ of the students in the normal library school stated that there are Z-libraries in their schools.

Table 4: How often do you go to the school library?

\begin{tabular}{|c|c|c|c|c|c|c|c|c|c|}
\hline \multirow{2}{*}{$\begin{array}{c}\text { Library Status at } \\
\text { Schools }\end{array}$} & \multicolumn{2}{|c|}{ Everyday } & \multicolumn{2}{|c|}{ Few times a week } & \multicolumn{2}{|c|}{ Once a month } & \multicolumn{2}{|c|}{ Never } & \multirow{2}{*}{ Total } \\
\hline & $\begin{array}{c}\text { Frequency } \\
\text { (f) }\end{array}$ & $\begin{array}{c}\text { Percentage } \\
(\%)\end{array}$ & \begin{tabular}{|c|}
$\begin{array}{c}\text { Frequency } \\
\text { (f) }\end{array}$ \\
\end{tabular} & $\begin{array}{c}\begin{array}{c}\text { Percentage } \\
(\%)\end{array} \\
\end{array}$ & $\begin{array}{l}\text { Frequency } \\
\text { (f) }\end{array}$ & $\begin{array}{c}\begin{array}{c}\text { Percentage } \\
(\%)\end{array} \\
\end{array}$ & $\begin{array}{l}\text { Frequency } \\
\text { (f) }\end{array}$ & $\begin{array}{c}\begin{array}{c}\text { Percentage } \\
(\%)\end{array} \\
\end{array}$ & \\
\hline Z-library & 18 & 4,5 & 84 & 21,0 & 53 & 13,3 & 45 & 11,3 & 200 \\
\hline Normal Library & 3 & ,8 & 13 & 3,3 & 66 & 16,5 & 118 & 29,5 & 200 \\
\hline TOTAL & 21 & 5,3 & 97 & 24,3 & 119 & 29,8 & 163 & 40,8 & 400 \\
\hline
\end{tabular}

In Table 4, it was aimed to measure the frequency of students going to school libraries according to the library status. While $4.5 \%$ of the Z-library students go to the library every day, this ratio is $0.8 \%$ in the normal library group. Those who visit a few times a week constitute $21.0 \%$ of the Zlibrary group, while this rate drops to $3.3 \%$ in the normal library group. In the Z-library group, $13.3 \%$ goes to the library once a month, while in the normal library group it is $16.5 \%$. Finally, those who have never been to the library make up $11.3 \%$ of the Z-library group and $29.5 \%$ of the normal library. 
Table 5: Do you know the time frame your school library is open?

\begin{tabular}{|c|c|c|c|c|c|c|c|}
\hline \multirow{2}{*}{$\begin{array}{c}\text { Library Status at } \\
\text { Schools }\end{array}$} & \multicolumn{2}{|c|}{ Yes } & \multicolumn{2}{c|}{ Partially } & \multicolumn{2}{c|}{ No } & \multirow{2}{*}{ Total } \\
\cline { 2 - 7 } & Frequency (f) & $\begin{array}{c}\text { Percentage } \\
(\%)\end{array}$ & Frequency (f) & $\begin{array}{c}\text { Percentage } \\
(\%)\end{array}$ & Frequency (f) & $\begin{array}{c}\text { Percentage } \\
(\%)\end{array}$ & \\
\hline Z-library & 103 & 25,8 & 96 & 24,0 & 1 &, 3 & 200 \\
\hline Normal Library & 75 & 18,8 & 123 & 30,8 & 2 &, 5 & 200 \\
\hline TOTAL & 178 & 44,6 & 219 & 54,8 & 3 &, 8 & 400 \\
\hline
\end{tabular}

In Table 5, the percentage of $25.8 \%$ of students in the Z-library group answered "Yes" to the question when the school library was open, while $18.8 \%$ of the students in the normal library group answered "Yes". The percentage of students who answered "partially" was $24.0 \%$ in the Z-library group and $30.8 \%$ in the normal library group. At the same time, $0.3 \%$ of those who prefer "No" are in the Z-library group while $0.5 \%$ are in the normal library group.

Table 6: In what time frame do you prefer to use the library at your school?

\begin{tabular}{|c|c|c|c|c|c|c|c|}
\hline \multirow[t]{2}{*}{$\begin{array}{c}\text { Library Status at } \\
\text { Schools }\end{array}$} & \multicolumn{2}{|c|}{ During recess } & \multicolumn{2}{|c|}{ Before/after classes } & \multicolumn{2}{|c|}{$\begin{array}{c}\text { During classes that } \\
\text { are not attended by } \\
\text { a teacher }\end{array}$} & \multirow[t]{2}{*}{ Total } \\
\hline & Frequency (f) & Percentage (\%) & Frequency (f) & Percentage $(\%)$ & Frequency (f) & $\begin{array}{c}\text { Percentag } \\
\mathrm{e}(\%)\end{array}$ & \\
\hline Z-library & 51 & 12,8 & 36 & 9,0 & 113 & 28,3 & 200 \\
\hline Normal Library & 54 & 13,5 & 20 & 200 & 126 & 31,5 & 200 \\
\hline TOTAL & 105 & 26,3 & 56 & 200 & 239 & 59,8 & 400 \\
\hline
\end{tabular}

In Table 6, it was aimed to determine which time frame students efficiently use the library. It was seen that the Z-library group has a $12.8 \%$ preference for recess hours and the normal library has $13.5 \%$. The percentage of people before/after classes are $9.0 \%$ in the Z-library group and $5.0 \%$ in the normal library group. Finally, the percentage of those who use the library during classes that are not attended by a teacher is $28.3 \%$ in the Z-library group and $31.5 \%$ in the normal library group. 
Table 7: For what purpose do you use the library?

\begin{tabular}{|c|c|c|c|c|c|}
\hline \multirow{2}{*}{ The Purpose of Using Libraries } & \multicolumn{2}{|c|}{ Z-library } & \multicolumn{2}{c|}{ Normal Library } & \multirow{2}{*}{ Total } \\
\cline { 2 - 5 } & Frequency(f) & $\begin{array}{c}\text { Percentage } \\
(\%)\end{array}$ & Frequency(f) & $\begin{array}{c}\text { Percentage } \\
(\%)\end{array}$ & \\
\hline To do homework & 38 & 9,5 & 17 & 4,25 & 13,75 \\
\hline To study & 74 & 18,5 & 91 & 22,75 & 41,25 \\
\hline To read books & 94 & 23,5 & 29 & 7,25 & 30,75 \\
\hline To borrow books & 83 & 20,75 & 25 & 6,25 & 27 \\
\hline To use the internet & 35 & 8,75 & 8 & 2 & 10,75 \\
\hline To relax & 27 & 6,75 & 26 & 6,5 & 13,25 \\
\hline To be with friends & 19 & 4,75 & 14 & 3,5 & 8,25 \\
\hline To utilize a technological device & 25 & 6,25 & 9 & 2,25 & 8,5 \\
\hline To play educational games & 7 & 1,75 & 2 & 0,5 & 2,25 \\
\hline Other & 10 & 2,5 & 42 & 10,5 & 13 \\
\hline
\end{tabular}

Table 7 seeks to investigate what purposes students have benefited from school libraries. Looking at these ratios, the Z-library group uses the library to do homework with a ratio of $9.5 \%$, while the normal library group's ratio is $4.25 \%$. The Z-library group's use to study is $18.5 \%$ while the normal library group's ratio is $22.75 \%$. The Z-library group uses $23.5 \%$ of the school library to read books while the normal library group uses $7.25 \%$. In order to borrow books, Z-library group uses $20,75 \%$ and normal library group uses $6,25 \%$. The Z-library group uses $8.75 \%$ of the library to use the internet while the normal library group uses $2 \%$. In addition, the Z-library group uses $6.25 \%$ of the library to relax while the normal library group uses $6.5 \%$. Also, the percentage of students using the library to be with friends is $4.75 \%$ in the Z-library group versus 3, 5\% in the normal library group. The Z-library group uses $6.25 \%$ of the library to utilize information technology using technological tools while the normal library group uses $2.25 \%$. At the same time, the ratio of those who use the library to play educational games is $1.75 \%$ in the Z-library group and $0.5 \%$ in the normal library group. The percentage of students who indicate that they do not use the library by choosing the other option is $2.5 \%$ in the Z-library group and $10.5 \%$ in the normal library group. 
Table 8: What is the impact of the school library on your academic success?

\begin{tabular}{|c|c|c|c|c|c|c|c|}
\hline \multirow{2}{*}{$\begin{array}{c}\text { Library Status at } \\
\text { Schools }\end{array}$} & \multicolumn{2}{|c|}{ Effective } & \multicolumn{2}{c|}{ Partially. } & \multicolumn{2}{c|}{ Non-effective } & \multirow{2}{*}{ Total } \\
\cline { 2 - 7 } & Frequency (f) & $\begin{array}{c}\text { Percentage } \\
(\%)\end{array}$ & Frequency (f) & $\begin{array}{c}\text { Percentage } \\
(\%)\end{array}$ & Frequency (f) & $\begin{array}{c}\text { Percentage } \\
(\%)\end{array}$ & \\
\hline Z-library & 87 & 21,8 & 78 & 19,5 & 35 & 8,8 & 200 \\
\hline Normal Library & 15 & 3,8 & 67 & 16,5 & 118 & 29,3 & 200 \\
\hline TOTAL & 102 & 25,6 & 144 & 36 & 152 & 38,1 & 400 \\
\hline
\end{tabular}

Table 8 seeks to determine the impact of school libraries on the academic success of secondary school students. In this respect, while the Z-library group believes with a ratio of $21.8 \%$ that school libraries are influencing academic achievement, this ratio is $3.8 \%$ in the normal library group. The percentage of the Z-library group that opted for the "partially" option was $19.5 \%$ while that of the normal library group was $16.5 \%$. Finally, $8.8 \%$ of the Z-library group preferred the non-effective option while $29.3 \%$ of the normal library group preferred it.

Table 9: How would it affect you if the number of borrowed books and most read books are informed on a digital database?

\begin{tabular}{|c|c|c|c|c|c|c|c|}
\hline \multirow{2}{*}{$\begin{array}{l}\text { Library } \\
\text { Status at } \\
\text { Schools }\end{array}$} & \multicolumn{2}{|c|}{$\begin{array}{l}\text { It would increase my } \\
\text { tendency to read. }\end{array}$} & \multicolumn{2}{|c|}{$\begin{array}{l}\text { It would not have any } \\
\text { effect on me. }\end{array}$} & \multicolumn{2}{|c|}{ Neutral } & \multirow{2}{*}{ Total } \\
\hline & Frequency (f) & Percentage (\%) & Frequency (f) & Percentage (\%) & Frequency (f) & Percentage (\%) & \\
\hline Z-library & 100 & 25,0 & 46 & 11,5 & 54 & 13,5 & 200 \\
\hline $\begin{array}{l}\text { Normal } \\
\text { Library }\end{array}$ & 55 & 13,8 & 65 & 16,3 & 80 & 20,0 & 200 \\
\hline TOTAL & 155 & 38,8 & 111 & 27,8 & 134 & 33,5 & 400 \\
\hline
\end{tabular}

Table 9 aims to investigate how students will be affected if information on the number of borrowed books and most read books are provided on a digital database. Taking this into consideration, the ratio of those who prefer to increase the reading tendency in the Z-library group is $25.0 \%$, whereas it is $13.8 \%$ in the normal library group. The percentage of students who think that there is no effect on them is $11,5 \%$ in the Z-library group and $16,3 \%$ in the normal library group. Finally, the ratio of people who are neutral is $13.5 \%$ in the Z-library group and $20.0 \%$ in the normal library group. 
Table 10: How does the presence or absence of a well-equipped library in your school affect your frequency to read books?

\begin{tabular}{|c|c|c|c|c|c|c|c|}
\hline $\begin{array}{c}\text { Library } \\
\text { Status at } \\
\text { Schools }\end{array}$ & \multicolumn{2}{|c|}{$\begin{array}{c}\text { It increases my interest } \\
\text { in reading. }\end{array}$} & \multicolumn{2}{|c|}{$\begin{array}{c}\text { It reduces my interest } \\
\text { in reading. }\end{array}$} & \multicolumn{2}{|c|}{ It does not affect. } & \multirow{2}{*}{ Total } \\
\cline { 2 - 7 } & Frequency (f) & $\begin{array}{c}\text { Percentage } \\
(\%)\end{array}$ & Frequency (f) & $\begin{array}{c}\text { Percentage } \\
(\%)\end{array}$ & Frequency (f) & Percentage (\%) & \\
\hline Z-library & 146 & 36,5 & 9 & 2,3 & 45 & 11,3 & 200 \\
\hline $\begin{array}{c}\text { Normal } \\
\text { Library }\end{array}$ & 83 & 20,8 & 15 & 3,8 & 102 & 25,5 & 200 \\
\hline TOTAL & 229 & 57,3 & 24 & 6,1 & 147 & 36,8 & 400 \\
\hline
\end{tabular}

Table 10 seeks to determine the way in which way the presence or absence of a well-equipped library in secondary education institutions influence the frequency of reading books. In this direction, we see that $36.5 \%$ of the Z-library group opted for increased interested in reading, while $20.8 \%$ in the normal library group. The $2.3 \%$ preferring to reduce interest in reading belongs to the Z-library group while the $3.8 \%$ rate belongs to the normal library group. Students who responded ineffectually form a rate of $11.3 \%$ in the Z-library group whereas this rate is $25.5 \%$ in the normal library group.

Table 11: Does having a well-trained library officer who guides, conveys reading levels to students affect your reading level?

\begin{tabular}{|c|c|c|c|c|c|c|c|}
\hline \multirow{2}{*}{$\begin{array}{l}\text { Library } \\
\text { Status at } \\
\text { Schools }\end{array}$} & \multicolumn{2}{|c|}{ Yes } & \multicolumn{2}{|c|}{ Partially } & \multicolumn{2}{|c|}{ No } & \multirow{2}{*}{ Tota } \\
\hline & Frequency (f) & Percentage (\%) & Frequency (f) & Percentage (\%) & Frequency (f) & Percentage (\%) & \\
\hline Z-library & 110 & 27,5 & 64 & 16,0 & 26 & 6,5 & 200 \\
\hline $\begin{array}{l}\text { Normal } \\
\text { Library }\end{array}$ & 73 & 18,3 & 62 & 15,5 & 65 & 16,3 & 200 \\
\hline TOTAL & 183 & 45,8 & 126 & 31,5 & 91 & 22,8 & 400 \\
\hline
\end{tabular}


In Table 11, it is aimed to determine how the presence of a well-trained library officer who guides readers in libraries and conveys them reading levels affect their level of reading. This ratio is $18.3 \%$ in the normal library group, while the "Yes" option in the Z-library group prefers a rate of $27.5 \%$. In the Z-library group, $16.0 \%$ responded "Partially", while $15.5 \%$ in the normal library group. Finally, $6.5 \%$ responded "no" in the Z-library group and $16.3 \%$ in the normal library group.

Table 12: Do you have access to sources in the school library? If not, why?

\begin{tabular}{|c|c|c|c|c|c|c|c|}
\hline \multirow{2}{*}{$\begin{array}{c}\text { Library Status } \\
\text { at Schools }\end{array}$} & \multicolumn{3}{|c|}{ I can. } & \multicolumn{2}{|}{$\begin{array}{c}\text { I cannot because there } \\
\text { are not enough } \\
\text { sources. }\end{array}$} & $\begin{array}{c}\text { I cannot because they } \\
\text { are not regular. }\end{array}$ & \multirow{2}{*}{ Total } \\
\cline { 2 - 7 } & Frequency (f) & $\begin{array}{c}\text { Percentage } \\
(\%)\end{array}$ & Frequency (f) & $\begin{array}{c}\text { Percentage } \\
(\%)\end{array}$ & Frequency (f) & $\begin{array}{c}\text { Percentage } \\
(\%)\end{array}$ & \\
\hline Z-library & 112 & 28,0 & 56 & 14,0 & 32 & 8,0 & 200 \\
\hline $\begin{array}{c}\text { Normal } \\
\text { Library }\end{array}$ & 77 & 19,3 & 80 & 20,0 & 43 & 10,8 & 200 \\
\hline TOTAL & 189 & 47,3 & 136 & 34 & 75 & 18,8 & 400 \\
\hline
\end{tabular}

Table 12 seeks to measure the impact of having or not having access to the sources they seek on students' reading. While the percentage of students reaching the sources they seek in the Zlibrary group is $28.0 \%$, this rate is $19.3 \%$ in the normal library group. The ratio of students who opted for "I cannot access because there are not enough sources" is $14.0 \%$ in the Z-library group and $20.0 \%$ in the normal library group. The ratio of students who opted for "I cannot because they are not regular" is $8.0 \%$ and this ratio is $10.8 \%$ in the normal library group.

Table 13: Can you access to current books in the school library?

\begin{tabular}{|c|c|c|c|c|c|c|c|}
\hline \multirow{2}{*}{$\begin{array}{l}\text { Library } \\
\text { Status at } \\
\text { Schools }\end{array}$} & \multicolumn{2}{|c|}{ Yes } & \multicolumn{2}{|c|}{ Partially } & \multicolumn{2}{|c|}{ No } & \multirow{2}{*}{ Total } \\
\hline & Frequency (f) & $\begin{array}{c}\begin{array}{c}\text { Percentage } \\
(\%)\end{array} \\
\end{array}$ & Frequency (f) & $\begin{array}{c}\begin{array}{c}\text { Percentage } \\
(\%)\end{array} \\
\end{array}$ & Frequency (f) & $\begin{array}{c}\begin{array}{c}\text { Percentage } \\
(\%)\end{array} \\
\end{array}$ & \\
\hline Z-library & 79 & 19,8 & 89 & 22,3 & 32 & 8,0 & 200 \\
\hline $\begin{array}{l}\text { Normal } \\
\text { Library }\end{array}$ & 27 & 6,8 & 87 & 21,8 & 86 & 21,5 & 200 \\
\hline TOTAL & 106 & 26,6 & 176 & 44,1 & 118 & 29,5 & 400 \\
\hline
\end{tabular}


Table 13 aims at seeing the impact of the presence of current books in libraries on reading. The ratio of $19.8 \%$ in the Z-library group chose the "Yes" option while this ratio is $6.8 \%$ in the normal library group. $22.3 \%$ of the respondents in the form chose "Partially" in the Z-library group, while $21.8 \%$ belong to the normal library group. The percentage of students who opted for the "No" option, indicating that they cannot, was $8.0 \%$ in the Z-library group versus $21.5 \%$ in the normal library group.

Table 14: Can you access books in the field of your interest in the school library?

\begin{tabular}{|c|c|c|c|c|c|c|c|}
\hline \multirow{2}{*}{$\begin{array}{l}\text { Library } \\
\text { Status at } \\
\text { Schools }\end{array}$} & \multicolumn{2}{|c|}{ Yes } & \multicolumn{2}{|c|}{ Partially } & \multicolumn{2}{|c|}{ No } & \multirow{2}{*}{ Total } \\
\hline & Frequency (f) & Percentage (\%) & Frequency (f) & Percentage $(\%)$ & Frequency (f) & Percentage (\%) & \\
\hline Z-library & 102 & 25,5 & 63 & 15,8 & 35 & 8,8 & 200 \\
\hline $\begin{array}{l}\text { Normal } \\
\text { Library }\end{array}$ & 39 & 9,8 & 74 & 18,5 & 87 & 21,8 & 200 \\
\hline TOTAL & 141 & 35,3 & 137 & 34,3 & 122 & 30,6 & 400 \\
\hline
\end{tabular}

Table 14 seeks to determine the effect on reading by asking them if they can reach the books in the areas they are interested. 25.5\% of the respondents who answered "Yes" belong to the Z-library group while $9.8 \%$ belong to the normal library group. While the Z-library group preferred the "Partially" response at $15.8 \%$, the normal library group preferred the "Partially" option at $18.5 \%$. "No" was in the Z-library group with $8.8 \%$, while the rate of $21.8 \%$ belonged to the normal library group. 
Table 15: Do the books at the school library fit your age?

\begin{tabular}{|c|c|c|c|c|c|c|c|}
\hline \multirow{2}{*}{$\begin{array}{c}\text { Library Status } \\
\text { at Schools }\end{array}$} & \multicolumn{2}{|c|}{ Yes } & \multicolumn{2}{c|}{ Partially } & \multicolumn{2}{c|}{ No } & \multirow{2}{*}{ Total } \\
\cline { 2 - 7 } & Frequency (f) & $\begin{array}{c}\text { Percentage } \\
(\%)\end{array}$ & Frequency (f) & $\begin{array}{c}\text { Percentage } \\
(\%)\end{array}$ & Frequency (f) & $\begin{array}{c}\text { Percentage } \\
(\%)\end{array}$ & \\
\hline Z-library & 148 & 37,0 & 37 & 9,3 & 15 & 3,8 & 200 \\
\hline $\begin{array}{c}\text { Normal } \\
\text { Library }\end{array}$ & 80 & 20,0 & 68 & 17,0 & 52 & 13,0 & 200 \\
\hline TOTAL & 228 & 57 & 105 & 26,3 & 67 & 16,8 & 400 \\
\hline
\end{tabular}

Table 15 seeks to determine whether the sources available in libraries are appropriate for the age of the students. In this case, the Z-library group says "Yes" at 37.0\%, while the normal library group says "Yes" at 20.0\%. While $9.3 \%$ of the respondents said "partly" belongs to the Z-library group, $17.0 \%$ belong to the normal library group. Finally, while the Z-library group gave "No" answer of $3.8 \%$, the normal library group gave a "No" answer of $13.0 \%$.

Table 16: Does the location of the in-school library influence whether you go to the library?

\begin{tabular}{|c|c|c|c|c|c|c|c|}
\hline \multirow[t]{2}{*}{$\begin{array}{l}\text { Library } \\
\text { Status at } \\
\text { Schools }\end{array}$} & \multicolumn{2}{|c|}{$\begin{array}{l}\text { I go more often because } \\
\text { it is easily accessed. }\end{array}$} & \multicolumn{2}{|c|}{$\begin{array}{l}\text { I go less often because } \\
\text { it is easily accessed. }\end{array}$} & \multicolumn{2}{|c|}{$\begin{array}{l}\text { Its location does not } \\
\text { affect me. }\end{array}$} & \multirow[t]{2}{*}{ Total } \\
\hline & Frequency (f) & Percentage (\%) & Frequency (f) & Percentage (\%) & Frequency (f) & Percentage $(\%)$ & \\
\hline Z-library & 66 & 16,5 & 41 & 10,3 & 93 & 23,3 & 200 \\
\hline $\begin{array}{l}\text { Normal } \\
\text { Library }\end{array}$ & 31 & 7,8 & 16 & 4,0 & 153 & 38,3 & 200 \\
\hline TOTAL & 97 & 24,3 & 57 & 14,3 & 246 & 61,6 & 400 \\
\hline
\end{tabular}

Table 16 seeks to determine whether the location of the in-school library influences whether students go to the library. As a result, $16.5 \%$ of the Z-library group opted for "I go more often because it is easily accessed" and the normal library group gave this answer at $7.8 \%$. The ratio of the Z-library group that chooses to go less because it is not easily accessed is $10,3 \%$, while it is $4.0 \%$ in the normal library group. The Z-library group gave a $23.3 \%$ answer that the location of the library does not affect me, while the normal library group gave the same answer at $38.3 \%$. 
Table 17: Do the current designs and colors of your library increase your desire to go to the library?

\begin{tabular}{|c|c|c|c|c|c|c|c|}
\hline \multirow{2}{*}{$\begin{array}{l}\text { Library } \\
\text { Status at } \\
\text { Schools }\end{array}$} & \multicolumn{2}{|c|}{ Yes } & \multicolumn{2}{|c|}{ Partially } & \multicolumn{2}{|c|}{ No } & \multirow{2}{*}{ Total } \\
\hline & Frequency (f) & $\begin{array}{c}\begin{array}{c}\text { Percentage } \\
(\%)\end{array} \\
\end{array}$ & Frequency (f) & $\begin{array}{c}\begin{array}{c}\text { Percentage } \\
(\%)\end{array} \\
\end{array}$ & Frequency (f) & $\begin{array}{c}\begin{array}{c}\text { Percentage } \\
(\%)\end{array} \\
\end{array}$ & \\
\hline Z-library & 132 & 33,0 & 41 & 10,3 & 27 & 6,8 & 200 \\
\hline $\begin{array}{l}\text { Normal } \\
\text { Library } \\
\end{array}$ & 24 & 6,0 & 53 & 13,3 & 123 & 30,8 & 200 \\
\hline TOTAL & 156 & 39 & 94 & 23,6 & 150 & 37,6 & 400 \\
\hline
\end{tabular}

Table 17 aims to determine if the design and colors of the libraries currently available increase the students' desire to go to the library. While the Z-library group gave the answer "Yes" at 33.0\%, the rate at the normal library group was $6.0 \%$. The Z-library group giving the "partially" answer is $10.3 \%$, while the normal library group is $13.3 \%$. Finally, the ratio of "z" to "no" is $6.8 \%$ while it is $30.8 \%$ in the normal library group.

Table 18: Is your school informed about libraries, books and the correct reading stages?

\begin{tabular}{|c|c|c|c|c|c|c|c|}
\hline $\begin{array}{c}\text { Library } \\
\text { Status at } \\
\text { Schools }\end{array}$ & \multicolumn{2}{|c|}{$\begin{array}{c}\text { It gives sufficient } \\
\text { information about } \\
\text { conscious reading }\end{array}$} & \multicolumn{2}{|c|}{$\begin{array}{c}\text { There is not any reading } \\
\text { activity. }\end{array}$} & $\begin{array}{c}\text { I am willing to read in } \\
\text { line with the } \\
\text { information I obtain. }\end{array}$ & \multirow{2}{*}{ Total } \\
\cline { 2 - 7 } & Frequency (f) & Percentage (\%) & Frequency (f) & Percentage (\%) & Frequency (f) & Percentage (\%) & \multirow{2}{*}{200} \\
\hline Z-library & 79 & 19,8 & 51 & 12,8 & 70 & 17,5 & 200 \\
\hline $\begin{array}{c}\text { Normal } \\
\text { Library }\end{array}$ & 42 & 10,5 & 75 & 18,8 & 83 & 20,8 & 200 \\
\hline TOTAL & 121 & 30,3 & 126 & 31,6 & 153 & 38,3 & 400 \\
\hline
\end{tabular}

Table 18 seeks to investigate whether information about libraries, books, and the correct reading stages is being given in secondary education institutions. While the Z-library group gave the 
answer that sufficient information about conscious reading is given at the rate of $19.8 \%$, the normal library group gave the same answer as $10.5 \%$. In the Z-library group gave the answer to the question "there is not any reading activity" at $12.8 \%$, while it is $18.8 \%$ in the normal library group. The normal library group gave the answer "I am willing to read in line with the information I obtain." with a percentage of $20.8 \%$, while the Z-library group's ratio is $17.5 \%$.

Questions 19-30 were asked in order to measure the creative reading consciousness in secondary school students.

Table 19: Do you know how to read by experiencing and exploring without the help of an instructor?

\begin{tabular}{|c|c|c|c|c|c|c|c|}
\hline \multirow{2}{*}{$\begin{array}{c}\text { Library } \\
\begin{array}{c}\text { Status at } \\
\text { Schools }\end{array}\end{array}$} & \multicolumn{2}{|c|}{ Yes } & \multicolumn{2}{c|}{ Partially } & \multicolumn{2}{c|}{ No } & \multirow{2}{*}{ Total } \\
\cline { 2 - 7 } & Frequency (f) & $\begin{array}{c}\text { Percentage } \\
(\%)\end{array}$ & Frequency (f) & $\begin{array}{c}\text { Percentage } \\
(\%)\end{array}$ & Frequency (f) & Percentage (\%) & \\
\hline Z-library & 138 & 34,5 & 44 & 11,0 & 18 & 4,5 & 200 \\
\hline $\begin{array}{c}\text { Normal } \\
\text { Library }\end{array}$ & 106 & 26,5 & 44 & 11,0 & 50 & 12,5 & 200 \\
\hline TOTAL & 244 & 61 & 88 & 22 & 68 & 17 & 400 \\
\hline
\end{tabular}

Table 19 seeks to measure whether students can knows how to read by experiencing and exploring without the help of an instructor. In this sense, "Yes" answer was given at the ratio of $34.5 \%$ in the Z-library group whereas "Yes" was given in $26.5 \%$ in the normal library group. The proportion of the Z-library group that gave the "partially" response is $11.0 \%$, while it is $11.0 \%$ in the normal library group. While the Z-library group preferring "no" has a rate of $4.5 \%$, the normal library has a rate of $12.5 \%$. 
Table 20: Before you start reading a book, do you make a systematic scan?

\begin{tabular}{|c|c|c|c|c|c|c|c|}
\hline \multirow{2}{*}{$\begin{array}{l}\text { Library } \\
\text { Status at } \\
\text { Schools }\end{array}$} & \multicolumn{2}{|c|}{ Yes } & \multicolumn{2}{|c|}{ Partially } & \multicolumn{2}{|c|}{ No } & \multirow{2}{*}{ Total } \\
\hline & Frequency (f) & $\begin{array}{c}\text { Percentage } \\
(\%)\end{array}$ & Frequency (f) & $\begin{array}{c}\text { Percentage } \\
(\%)\end{array}$ & Frequency (f) & Percentage $(\%)$ & \\
\hline Z-library & 87 & 21,8 & 74 & 18,5 & 39 & 9,8 & 200 \\
\hline $\begin{array}{l}\text { Normal } \\
\text { Library }\end{array}$ & 58 & 14,5 & 57 & 14,3 & 85 & 21,3 & 200 \\
\hline TOTAL & 145 & 36,3 & 131 & 32,8 & 124 & 31,1 & 400 \\
\hline
\end{tabular}

Table 20 seeks to measure whether students make a systematic scan before they start reading a book. According to this, while the Z-library group gave a "Yes" answer of $21.8 \%$ ratio, the normal library group gave a "Yes" answer of $14.5 \%$. While the Z-library group gave the answer "Partially" at $18.5 \%$, this rate was $14.3 \%$ in the normal library group. It is seen that the Z-library group preferring "No" has a rate of $9.8 \%$, while the normal library group has a rate of $21.3 \%$.

Table 21: When you read a book, do you try to ask a question to the text and answer yourself again?

\begin{tabular}{|c|c|c|c|c|c|c|c|}
\hline \multirow{2}{*}{$\begin{array}{c}\text { Library } \\
\begin{array}{c}\text { Status at } \\
\text { Schools }\end{array}\end{array}$} & \multicolumn{2}{|c|}{ Yes } & \multicolumn{2}{c|}{ Partially } & \multicolumn{2}{c|}{ No } & \multirow{2}{*}{ Total } \\
\cline { 2 - 7 } & Frequency (f) & Percentage (\%) & Frequency (f) & Percentage (\%) & Frequency (f) & Percentage (\%) & \\
\hline Z-library & 83 & 20,8 & 58 & 14,5 & 59 & 14,8 & 200 \\
\hline $\begin{array}{c}\text { Normal } \\
\text { Library }\end{array}$ & 62 & 15,5 & 51 & 12,8 & 87 & 21,8 & 200 \\
\hline TOTAL & 145 & 36,3 & 109 & 27,3 & 146 & 36,6 & 400 \\
\hline
\end{tabular}

Table 21 seeks to measure whether students are attempting to ask themselves questions and answer while reading a book. In this direction, the Z-library group gives a "Yes" answer at 20.8\%, whereas in a normal library this rate is $\mathbf{1 5 . 5 \%}$. The rate of the Z-library group giving "partially" response 
is $14.5 \%$ while it is $12.8 \%$ in the normal library group. Finally, the "no" answer in the Z-library group covers a percentage of $14.8 \%$, while in the normal library group this percentage is $21.8 \%$.

Table 22: Do you usually know what the sentences in the book you read are trying to say?

\begin{tabular}{|c|c|c|c|c|c|c|c|}
\hline \multirow{2}{*}{$\begin{array}{c}\text { Library } \\
\text { Status at } \\
\text { Schools }\end{array}$} & \multicolumn{2}{|c|}{ Yes } & \multicolumn{2}{c|}{ Partially } & \multicolumn{2}{c|}{ No } & \multirow{2}{*}{ Total } \\
\cline { 2 - 7 } & Frequency (f) & Percentage (\%) & Frequency (f) & Percentage (\%) & Frequency (f) & Percentage (\%) & \\
\hline Z-library & 150 & 37,5 & 35 & 8,8 & 15 & 3,8 & 200 \\
\hline $\begin{array}{c}\text { Normal } \\
\text { Library }\end{array}$ & 119 & 29,8 & 45 & 11,3 & 36 & 9,0 & 200 \\
\hline TOTAL & 269 & 67,3 & 80 & 20,1 & 51 & 12,8 & 400 \\
\hline
\end{tabular}

Table 22 seeks to measure whether students often know what the sentences in the book they read are trying to say. According to this, the Z-library group gives the answer "Yes" at $37.5 \%$ while the rate of the normal library group is $29.8 \% .8 .8 \%$ of the students who answered "partially" belong to the Z-library group, while $11.3 \%$ belong to the normal library group. Finally, the Z-library group that chooses "No" creates a percentage of $3.8 \%$ while the normal library group makes a percentage of $9.0 \%$.

Table 23: When you read, do you look up for the words you do not know the meaning of?

\begin{tabular}{|c|c|c|c|c|c|c|c|}
\hline \multirow{2}{*}{$\begin{array}{l}\text { Library } \\
\text { Status at } \\
\text { Schools }\end{array}$} & \multicolumn{2}{|c|}{ Yes } & \multicolumn{2}{|c|}{ Partially } & \multicolumn{2}{|c|}{ No } & \multirow{2}{*}{ Total } \\
\hline & Frequency (f) & Percentage $(\%)$ & Frequency (f) & Percentage $(\%)$ & Frequency (f) & Percentage $(\%)$ & \\
\hline Z-library & 107 & 26,8 & 64 & 16,0 & 29 & 7,3 & 200 \\
\hline $\begin{array}{l}\text { Normal } \\
\text { Library }\end{array}$ & 65 & 16,3 & 75 & 18,8 & 60 & 15,0 & 200 \\
\hline TOTAL & 172 & 43,1 & 139 & 34,8 & 89 & 22,3 & 400 \\
\hline
\end{tabular}

Table 23 seeks to measure whether students look up for the words that they do not understand while reading. In this context, while the Z-library group gave a "Yes" answer at $26.8 \%$, it is seen that this ratio is $16.3 \%$ in the normal library group. Percentage values giving the "partialy" answer are $16.0 \%$ in the Z-library group and $18.8 \%$ in the normal library group. Finally, while the Z- 
library group, which prefers "no" accounts for 7.3\%, the normal library group accounts for $15.0 \%$.

Table 24: Do you question and criticize while reading?

\begin{tabular}{|c|c|c|c|c|c|c|c|}
\hline \multirow{2}{*}{$\begin{array}{c}\text { Library } \\
\text { Status at } \\
\text { Schools }\end{array}$} & \multicolumn{2}{|c|}{ Yes } & \multicolumn{2}{|c|}{ Partially } & \multicolumn{2}{|c|}{ No } & \multirow{2}{*}{ Total } \\
\hline & Frequency (f) & $\begin{array}{c}\text { Percentage } \\
(\%)\end{array}$ & Frequency (f) & $\begin{array}{c}\text { Percentage } \\
(\%)\end{array}$ & Frequency (f) & Percentage $(\%)$ & \\
\hline Z-library & 128 & 32,0 & 51 & 12,8 & 21 & 5,3 & 200 \\
\hline $\begin{array}{l}\text { Normal } \\
\text { Library } \\
\end{array}$ & 79 & 19,8 & 80 & 20,0 & 41 & 10,3 & 200 \\
\hline TOTAL & 207 & 51,8 & 131 & 32,8 & 62 & 15,6 & 400 \\
\hline
\end{tabular}

Table 24 seeks to measure students' questioning and criticism while reading. According to this, the proportion of people who answered "Yes" in the Z-library group was 32.0\% while this rate was $19.8 \%$ in the normal library group. Those who gave "partially" answers were $12.8 \%$ in the Zlibrary group and $20.0 \%$ in the normal library group. While those who prefer "no" make up 5.3\% of the Z-library group, they make up $10.3 \%$ of the normal library group.

Table 25: Do you have difficulty while reading and have to read repeatedly?

\begin{tabular}{|c|c|c|c|c|c|c|c|}
\hline \multirow{2}{*}{$\begin{array}{c}\text { Library } \\
\begin{array}{c}\text { Status at } \\
\text { Schools }\end{array}\end{array}$} & \multicolumn{2}{|c|}{ Yes } & \multicolumn{2}{c|}{ Partially } & \multicolumn{2}{c|}{ No } & \multirow{2}{*}{ Total } \\
\cline { 2 - 7 } & Frequency (f) & Percentage (\%) & Frequency (f) & Percentage (\%) & Frequency (f) & Percentage (\%) & \\
\hline Z-library & 77 & 19,3 & 62 & 15,5 & 61 & 15,3 & 200 \\
\hline $\begin{array}{c}\text { Normal } \\
\text { Library }\end{array}$ & 79 & 19,8 & 64 & 16,0 & 57 & 14,3 & 200 \\
\hline TOTAL & 156 & 39,1 & 126 & 31,5 & 118 & 29,6 & 400 \\
\hline
\end{tabular}

Table 25 seeks to measure the extent to which students have difficulty while reading and have to read repeatedly. In this case, the rate of "yes" answer of the Z-library group is $19.3 \%$ while that of 
the normal library group is $19.8 \%$. "Partially" the percentages are $15.5 \%$ in the $\mathrm{z}-0$ is. Finally, the Z-library group that chooses the "no" option gets a $15.3 \%$ share while the normal library group gets a $14.3 \%$ share.

Table 26: Can you decide what kind of instructive the book is when you read it?

\begin{tabular}{|c|c|c|c|c|c|c|c|}
\hline $\begin{array}{c}\text { Library } \\
\begin{array}{c}\text { Status at } \\
\text { Schools }\end{array}\end{array}$ & \multicolumn{2}{|c|}{ Yes } & \multicolumn{2}{c|}{ Partially } & \multicolumn{2}{c|}{ No } & \multirow{2}{*}{ Total } \\
\cline { 2 - 7 } & Frequency (f) & Percentage (\%) & Frequency (f) & Percentage (\%) & Frequency (f) & Percentage (\%) \\
\hline Z-library & 140 & 35,0 & 41 & 10,3 & 19 & 4,8 & 200 \\
\hline $\begin{array}{c}\text { Normal } \\
\text { Library }\end{array}$ & 108 & 27,0 & 56 & 14,0 & 36 & 9,0 & 200 \\
\hline TOTAL & 248 & 62 & 97 & 24,3 & 55 & 13,8 & 400 \\
\hline
\end{tabular}

Table 26 seeks to measure whether students can decide whether or not the book is instructive while reading. According to this, the Z-library group gives a response of "Yes" at 35.0\% while this rate is $27.0 \%$ in the normal library group. "Partially" percentages are $10.3 \%$ in the Z-library group and $14.0 \%$ in the normal library group. Finally, the Z-library group that chooses "No" rate gets $4.8 \%$ while the normal library group gets $9.0 \%$.

Table 27: When the book you are reading is finished, do you have a level of opinion to explain it to someone else?

\begin{tabular}{|c|c|c|c|c|c|c|c|}
\hline \multirow{2}{*}{$\begin{array}{c}\text { Library } \\
\text { Status at } \\
\text { Schools }\end{array}$} & \multicolumn{2}{|c|}{ Yes } & \multicolumn{2}{c|}{ Partially } & \multicolumn{2}{c|}{ No } & \multirow{2}{*}{ Total } \\
\cline { 2 - 7 } & Frequency (f) & Percentage (\%) & Frequency (f) & Percentage (\%) & Frequency (f) & Percentage (\%) \\
\hline Z-library & 163 & 40,8 & 24 & 6,0 & 12 & 3,0 & \multirow{2}{*}{200} \\
\hline $\begin{array}{c}\text { Normal } \\
\text { Library }\end{array}$ & 136 & 34,0 & 35 & 8,8 & 29 & 7,3 & 200 \\
\hline TOTAL & 300 & 74,8 & 59 & 14,8 & 41 & 10,3 & 400 \\
\hline
\end{tabular}

Table 27 seeks to measure whether or not students have enough opinions to tell someone else when their books are finished. In this context, Z-library group gives 40.8\% "Yes" response while normal library group has $34.0 \%$. While the Z-library group answers "Partially" at $6.0 \%$, the normal library 
group answers "Partially" at $8.8 \%$. The percentages of those who prefer "No" are $3.0 \%$ in the Zlibrary group and $7.3 \%$ in the normal library group.

Table 28: Can you make links between words, phrases, and paragraphs while reading a book?

\begin{tabular}{|c|c|c|c|c|c|c|c|}
\hline \multirow{2}{*}{$\begin{array}{l}\text { Library } \\
\text { Status at } \\
\text { Schools }\end{array}$} & \multicolumn{2}{|c|}{ Yes } & \multicolumn{2}{|c|}{ Partially } & \multicolumn{2}{|c|}{ No } & \multirow{2}{*}{ Total } \\
\hline & Frequency (f) & Percentage (\%) & Frequency (f) & Percentage (\%) & Frequency (f) & Percentage (\%) & \\
\hline Z-library & 160 & 40,0 & 29 & 7,3 & 10 & 2,5 & 200 \\
\hline $\begin{array}{l}\text { Normal } \\
\text { Library }\end{array}$ & 125 & 31,3 & 43 & 10,8 & 32 & 8,0 & 200 \\
\hline TOTAL & 285 & 71,3 & 72 & 18,1 & 42 & 10,5 & 400 \\
\hline
\end{tabular}

Table 28 seeks to measure situations in which whether students link words, phrases, and paragraphs while reading a book. The rate of $31.3 \%$ in the normal library group gave the answer "yes" while 40.0\%, gave the same answer in the Z-library group. While $7.3 \%$ of those who prefer the "partially" answer are in the Z-library group, $10.8 \%$ are in the normal library. Finally, the percentages of those who prefer "No" are $2.5 \%$ in the Z-library group while it is $8.0 \%$ in the normal library group.

Table 29: Can you identify the author's key words and premises while reading a book?

\begin{tabular}{|c|c|c|c|c|c|c|c|}
\hline \multirow{2}{*}{$\begin{array}{l}\text { Library } \\
\text { Status at } \\
\text { Schools }\end{array}$} & \multicolumn{2}{|c|}{ Yes } & \multicolumn{2}{|c|}{ Partially } & \multicolumn{2}{|c|}{ No } & \multirow{2}{*}{ Total } \\
\hline & Frequency (f) & Percentage (\%) & Frequency (f) & Percentage (\%) & Frequency (f) & Percentage (\%) & \\
\hline Z-library & 109 & 27,3 & 74 & 18,5 & 17 & 4,3 & 200 \\
\hline $\begin{array}{l}\text { Normal } \\
\text { Library }\end{array}$ & 87 & 21,8 & 67 & 16,8 & 46 & 11,5 & 200 \\
\hline TOTAL & 196 & 49,1 & 141 & 35,3 & 63 & 15,8 & 400 \\
\hline
\end{tabular}

International Association of School Librarianship https://www.iasl-online.org/ 
Table 29 seeks to measure whether students can determine the key words and premises of the author while reading a book. While the Z-library group gave the answer "Yes" in $27.3 \%$, this rate was $21.8 \%$ in the normal library group. There is an $18.5 \%$ portion in the Z-library group that gives the "partially" answer, and a $16.8 \%$ portion in the normal library group. Finally, the percentage of those who prefer "no" is $4.3 \%$ in the Z-library group and $11.5 \%$ in the normal library group.

Table 30: When you finish a book, can you create a personal view rather than the author's view?

\begin{tabular}{|c|r|r|r|r|r|r|c|}
\hline \multirow{2}{*}{$\begin{array}{c}\text { Library } \\
\begin{array}{c}\text { Status at } \\
\text { Schools }\end{array}\end{array}$} & \multicolumn{2}{|c|}{ Yes } & \multicolumn{2}{|c|}{ Partially } & \multicolumn{2}{|c|}{ No } & \multirow{2}{*}{ Total } \\
\cline { 2 - 7 } & Frequency (f) & Percentage (\%) & Frequency (f) & Percentage (\%) & Frequency (f) & Percentage (\%) \\
\hline Z-library & 145 & 36,3 & 46 & 11,5 & 8 & 2,0 & 200 \\
\hline $\begin{array}{l}\text { Normal } \\
\text { Library }\end{array}$ & 110 & 27,5 & 49 & 12,3 & 41 & 10,3 & 200 \\
\hline TOTAL & 255 & 63,8 & 95 & 23,8 & 49 & 12,3 & 400 \\
\hline
\end{tabular}

Table 30 seeks to measure whether students can create a specific view rather than the author's view when they finish a book. Accordingly, percentages are $36.3 \%$ in the Z-library group and $27.5 \%$ in the normal library group. While the "Partially" respondents in the Z-library group constituted $11.5 \%$, the normal library group constituted $12.3 \%$. At the same time, we see that the rates giving the "no" answer are $2.0 \%$ in the $\mathrm{Z}$ library group, but $10.3 \%$ in the normal library group.

\section{Questions Z1-Z6 were asked to students with z-libraries in their schools.}

Table Z1: Do you have information about Z-library (Enriched Library)?

\begin{tabular}{|c|c|c|c|c|c|c|c|}
\hline \multirow{2}{*}{$\begin{array}{l}\text { Library } \\
\text { Status at } \\
\text { Schools }\end{array}$} & \multicolumn{2}{|c|}{ Yes } & \multicolumn{2}{|c|}{ Partially } & \multicolumn{2}{|c|}{ No } & \multirow{2}{*}{ Total } \\
\hline & Frequency (f) & Percentage (\%) & Frequency (f) & Percentage (\%) & Frequency (f) & Percentage (\%) & \\
\hline Z-library & 116 & 58,0 & 48 & 24,0 & 26 & 13,0 & 200 \\
\hline
\end{tabular}

Table Z1 aims to measure students' knowledge of the Z-library. In this direction, Z-library group 
answered "Yes" with 58.0\%, "Partially" with $24.0 \%$ and "No" with $13.0 \%$.

Table Z2: What is the most beneficial aspect of the Z-library project?

\begin{tabular}{|c|c|c|c|c|c|c|c|c|c|c|c|}
\hline \multirow[t]{2}{*}{$\begin{array}{l}\text { Library } \\
\text { Status at } \\
\text { Schools }\end{array}$} & \multicolumn{2}{|c|}{$\begin{array}{l}\text { Providing } \\
\text { access to } \\
\text { different } \\
\text { sources of } \\
\text { information }\end{array}$} & \multicolumn{2}{|c|}{$\begin{array}{c}\text { Including } \\
\text { digital sources } \\
\text { as well as } \\
\text { printed } \\
\text { resources } \\
\end{array}$} & \multicolumn{2}{|c|}{$\begin{array}{l}\text { Providing } \\
\text { students' need } \\
\text { to play } \\
\text { computer } \\
\text { games } \\
\end{array}$} & \multicolumn{2}{|c|}{$\begin{array}{c}\text { Providing a } \\
\text { comfortable } \\
\text { environment } \\
\text { for students to } \\
\text { study } \\
\end{array}$} & \multicolumn{2}{|c|}{ Other } & \multirow[t]{2}{*}{ Total } \\
\hline & $\begin{array}{l}\text { Frequen } \\
\text { cy (f) }\end{array}$ & $\begin{array}{c}\text { Percenta } \\
\text { ge }(\%)\end{array}$ & $\begin{array}{l}\text { Frequen } \\
\text { cy (f) }\end{array}$ & $\begin{array}{l}\text { Percenta } \\
\text { ge }(\%)\end{array}$ & $\begin{array}{l}\text { Frequen } \\
\text { cy (f) }\end{array}$ & $\begin{array}{c}\text { Percenta } \\
\text { ge (\%) }\end{array}$ & $\begin{array}{l}\text { Frequen } \\
\text { cy (f) }\end{array}$ & $\begin{array}{c}\text { Percenta } \\
\text { ge (\%) }\end{array}$ & $\begin{array}{l}\text { Frequen } \\
\text { cy (f) }\end{array}$ & $\begin{array}{c}\text { Percenta } \\
\text { ge }(\%)\end{array}$ & \\
\hline Z-library & 72 & 36,0 & 55 & 27,5 & 21 & 10,5 & 50 & 25,0 & 2 & 1,0 & 200 \\
\hline
\end{tabular}

Table Z2 seeks to determine which aspects students find more useful in the Z-library. In this sense, the Z-library group preferred the option of "Providing access to different sources of information" at a rate of $36.0 \%$ and $27.5 \%$ at the option of "Including digital sources as well as printed resources". $10.5 \%$ of the students preferred the option "Providing students' need to play computer games and $25.0 \%$ preferred the option "Providing a comfortable environment for students to study". Finally, it appears that only $1.0 \%$ of students use the "Other" preference.

Table Z3: How important is it for you to have "electronic books" so that you can benefit more from your Z-library at your school?

\begin{tabular}{|c|c|c|c|c|c|c|c|}
\hline $\begin{array}{c}\text { Library } \\
\text { Status at } \\
\text { Schools }\end{array}$ & \multicolumn{2}{|c|}{ Important } & \multicolumn{2}{|c|}{ Partially important } & \multicolumn{2}{|c|}{ Unimportant } & \multirow{2}{*}{ Total } \\
\cline { 2 - 6 } & Frequency (f) & Percentage (\%) & Frequency (f) & Percentage (\%) & Frequency (f) & Percentage (\%) & \\
\hline Z-library & 109 & 54,5 & 58 & 29,0 & 27 & 13,5 & \multirow{2}{*}{200} \\
\hline
\end{tabular}

International Association of School Librarianship https://www.iasl-online.org/ 
Table Z3 seeks to investigate how important it is for them to have "electronic books" so that students can benefit more from the Z-library in schools. According to this, it is seen that 54,5\% prefer the "Important" option, 29,0\% prefer the "Partially important" option and 13,5\% prefer the "Unimportant" option.

Table Z4: Does the introduction of information technology into school libraries affect you positively or negatively in terms of information access?

\begin{tabular}{|c|c|c|c|c|c|c|c|}
\hline $\begin{array}{c}\text { Library } \\
\text { Status at } \\
\text { Schools }\end{array}$ & \multicolumn{2}{|c|}{ Positively. } & \multicolumn{2}{c|}{ Partially } & \multicolumn{2}{|c|}{ Negatively. } & \multirow{2}{*}{ Total } \\
\cline { 2 - 7 } & Frequency (f) & Percentage (\%) & Frequency (f) & Percentage (\%) & Frequency (f) & Percentage (\%) & \\
\hline Z-library & 117 & 58,5 & 54 & 27,0 & 20 & 10,0 & 200 \\
\hline
\end{tabular}

Table Z4 aims to investigate whether the introduction of information technology into school libraries influences students positively or negatively. According to this, it is observed that $58.5 \%$ of the respondents prefer "positively", $27.0 \%$ of the respondents prefer the "partially" response and $10.0 \%$ of the respondents prefer the negative response.

Table Z5: How often did you go to the library before the Z-library was introduced?

\begin{tabular}{|c|c|c|c|c|c|c|c|c|c|c|c|}
\hline \multirow{2}{*}{$\begin{array}{c}\text { Library } \\
\text { Status at } \\
\text { Schools }\end{array}$} & \multicolumn{2}{|c|}{ Everyday } & \multicolumn{2}{|c|}{$\begin{array}{l}\text { Few times a } \\
\text { week }\end{array}$} & \multicolumn{2}{|c|}{ Once a month } & \multicolumn{2}{|c|}{ Once a year } & \multicolumn{2}{|c|}{ Never } & \multirow{2}{*}{ Total } \\
\hline & $\begin{array}{c}\text { Frequen } \\
\text { cy (f) }\end{array}$ & $\begin{array}{l}\text { Percent } \\
\text { age }(\%)\end{array}$ & $\begin{array}{c}\text { Frequen } \\
\text { cy (f) }\end{array}$ & $\begin{array}{l}\text { Percent } \\
\text { age (\%) }\end{array}$ & $\begin{array}{c}\text { Frequen } \\
\text { cy }(\mathrm{f})\end{array}$ & $\begin{array}{l}\text { Percent } \\
\text { age }(\%)\end{array}$ & $\begin{array}{c}\text { Frequen } \\
\text { cy (f) }\end{array}$ & $\begin{array}{l}\text { Percent } \\
\text { age (\%) }\end{array}$ & $\begin{array}{c}\text { Frequen } \\
\text { cy }(\mathrm{f})\end{array}$ & $\begin{array}{l}\text { Percent } \\
\text { age (\%) }\end{array}$ & \\
\hline Z-library & 8 & 4,0 & 23 & 11,5 & 72 & 36,0 & 38 & 19,0 & 59 & 29,5 & 200 \\
\hline
\end{tabular}

Table Z5 seeks to measure the frequency of students going to the library before the Z-library was established. The rate of going to the library every day is $4,0 \%$, the rate of going a few times a week is $11,5 \%$, the rate of going once a month is $36,0 \%$, the rate of going once a year is $19,0 \%$ and 
finally the rate of never going is $29,5 \%$.

Table Z6: How often do you go to the library after the Z-library was introduced?

\begin{tabular}{|c|c|c|c|c|c|c|c|c|c|c|c|}
\hline \multirow{2}{*}{$\begin{array}{l}\text { Library } \\
\text { Status at } \\
\text { Schools }\end{array}$} & \multicolumn{2}{|c|}{ Everyday } & \multicolumn{2}{|c|}{$\begin{array}{c}\text { Few times a } \\
\text { week }\end{array}$} & \multicolumn{2}{|c|}{ Once a month } & \multicolumn{2}{|c|}{ Once a year } & \multicolumn{2}{|c|}{ Never } & \multirow{2}{*}{ Total } \\
\hline & $\begin{array}{l}\text { Frequen } \\
\text { cy (f) }\end{array}$ & $\begin{array}{l}\text { Percent } \\
\text { age (\%) }\end{array}$ & $\begin{array}{l}\text { Frequen } \\
\text { cy (f) }\end{array}$ & $\begin{array}{l}\text { Percent } \\
\text { age }(\%)\end{array}$ & $\begin{array}{l}\text { Frequen } \\
\text { cy (f) }\end{array}$ & $\begin{array}{l}\text { Percent } \\
\text { age (\%) }\end{array}$ & $\begin{array}{l}\text { Frequen } \\
\text { cy (f) }\end{array}$ & $\begin{array}{l}\text { Percent } \\
\text { age }(\%)\end{array}$ & $\begin{array}{l}\text { Frequen } \\
\text { cy (f) }\end{array}$ & $\begin{array}{l}\text { Percent } \\
\text { age }(\%)\end{array}$ & \\
\hline Z-library & 44 & 22,0 & 86 & 43,0 & 52 & 26,0 & 4 & 2,0 & 14 & 7,0 & 200 \\
\hline
\end{tabular}

Table Z6 aims to measure how often students go to the library after Z-library was established. The rate of going to the library every day is $22.0 \%$, the percentage of those going a few times per week is $43.0 \%$, the rate of going once a month is $26.0 \%$, and the rate of going once a year is $2.0 \%$ and finally the rate of those who never going is $7.0 \%$.

\section{Results and Discussion}

The results obtained through the works are as follows:

- $\quad$ Reading habits are more common in secondary education institutions with z-libraries.

- The development of reading culture is influenced by school libraries because the level of reading in secondary schools with normal libraries is lower than the level of reading in secondary schools with well-equipped school libraries such as z-libraries.

- Secondary school students have different aims from libraries. For example, students in secondary schools with z-libraries are benefiting from the library mainly with the purpose of reading books and borrowing books while students in secondary schools that have a normal library reported that they are benefiting mainly with the purpose of studying in the library. Also by opting for other options they reported they are not benefitting from 
the library.

- According to the findings, the majority of the students in the Z-library schools reported that these libraries positively influenced their academic achievement.

- Information about the most read books of school libraries in the digital database increases the interest in reading.

- The presence of a well-trained library officer who guides readers in libraries and conveys reading levels to students affects the reading level positively.

- It encourages students to have various, current and age range books in the library.

- While the location of the library does not affect many students' habit of going to the library, the design of libraries affects them.

- In the questionnaires, the results of the questions covering 18-30 questions and measuring the level of creative reading of the students shown that creative reading is done more consciously in Z-library schools.

- Students are aware of the benefits and environment provided by the Z-library.

- The fact that e-books exist in the Z-libraries increases the interest in reading.

- The introduction of information technologies into the Z- libraries affects students' access to information positively.

- The establishment of z-libraries in secondary schools positively influenced students' habits of going to the library. The rate of those who never goes to libraries or goes once a month or year decreased.

\section{Recommendations}

- Since it is seen that Z-libraries have positive effects on the development of reading habits, the work on introducing a Z-library to each school can be accelerated.

- There should be well-equipped library officers who guide and convey reading levels to 
students in libraries.

- Information about the most read books of school libraries should be provided in the digital database.

- Books in libraries should be various, current and of age range.

- Libraries should be developed in terms of design.

- Z-libraries should have equipped informative tools.

- Students should be given technical information about the use of Z-libraries.

- Activities such as contests, educational games, and drama studies, reading books at certain hours, and chatting about books on a day in the week should be carried out in the libraries through qualified books.

- E-books should be available on Z-library computers for young readers who do reading through phones, tablets, laptops, computers etc. with the advanced technology.

- The student who reads the most each month should be identified, rewarded and announced to the other students in order to encourage the students to read.

- Much of the work on the library should be carried out by students, and a special panel for the library should be organized by them every week.

- Students should be asked to share their thoughts on any book they often read on the library panels, so that they can be seen by other students.

- Students, library staff and administrators should be in contact for the library work. 


\section{Bibliography}

Akkaya, M. (2015). Milli Eğitim Bakanlığı Bünyesinde Hizmet Veren Lise Kütüphanelerinin Niceliksel Analizi: İzmir Buca Örneği, Milli Eğitim Dergisi, 44 (208), 174-191

Atılgan, D. (1995). Türkiye'de Kütüphaneciliğin Gelişimi, Türk Kütüphaneciliği 9, 1 (1995), 10-20

Çetintaş, H. (2015). Eğitimde Zenginleştirilmiş Kütüphanelerin Yeri ve Önemi: Ahmet Mesut Yılmaz İlkokulu Zenginleştirilmiş Kütüphane Uygulamas1, Milli Eğitim Dergisi, 44 (208), 18-32

IFLA/UNESCO Okul Kütüphanesi Bildirgesi, 2002, Erişim tarihi: 21.12.2015, http://www.kutuphaneci.org.tr/ifla-unesco-okul-kutuphanesi-bildirgesi

Karatay, H. (2015). Eleştirel Düşünme ve Okuma Becerilerinin Geliştirilmesi İçin Edebiyat Halkası: Kitap Eleştirisi Modeli, Milli Eğitim Dergisi, 44 (208), 7-17

MEB Uluslararası Öğrenci Değerlendirme Programı PISA 2009 Ulusal Ön Raporu, Ankara 2010, Erişim tarihi: 18.10. 2015 http://pisa.meb.gov.tr/wp-content/uploads/2013/07/PISA-2009-Ulusal-OnRapor.pdf

MEB Uluslararası Öğrenci Değerlendirme Programı PISA 2012 Ulusal Ön Raporu, Ankara 2013, Erişim tarihi: 18.10. 2015, http://pisa.meb.gov.tr/wp-content/uploads/2013/12/pisa2012-ulusal-onraporu.pdf

Milli Eğitim Bakanlığı Zenginleştirilmiş Kütüphaneler Etki Analiz Araştırması, Erişim tarihi: 16 Kasım 2015, http://dhgm.meb.gov.tr/dosyalar/2 kutuphane etki arast\%C4\%B1rmasi.pdf

Taştan, C. (2015). Gençler, Kitaplar ve Kütüphaneler, Milli Eğitim Bakanlı̆̆ı Yeğitek Dergisi, say1 13, 20 23 